\title{
Peningkatan Penalaran Ilmiah Siswa melalui Pembelajaran Guided Inquiry Berstrategi Scaffolding pada Materi Suhu dan Kalor
}

\author{
Putri Dwi Sundari ${ }^{1)}$ Ety Rimadani $^{2)}$ \\ ${ }^{1)}$ Pendidikan Fisika, Jurusan Fisika Universitas Negeri Padang \\ ${ }^{2)}$ Great Crystal School, Surabaya \\ putridwisundari@fmipa.unp.ac.id
}

\begin{abstract}
The purpose of this research was to analyze the students' scientific reasoning skills in the guided inquiry learning integrated of scaffolding in heat and temperature. The research used mixedmethod with embedded experimental design. The subject of this research was 29 students of class X in Sidoarjo state high school. The instrument consists of treatment and measurement instruments. The treatment instruments consist of syllabus, lesson plan, and student worksheet. The measurement instrument consists of scientific reasoning skills test. The test development based on scientific reasoning pattern proposed by Lawson with a reliability of 0.848. The quantitative data on students' scientific reasoning skills was analyzed using Wilcoxon-test, while qualitative data was analyzed by reducing data and coding using a scientific reasoning pattern rubric. The results show that students' scientific reasoning skill in heat and temperature increased after following the guided inquiry learning integrated of scaffolding. The students have been able to use information to determine whether a conclusion is likely to be true or not, but students are still unable to recognize and interpret relationships in situations described by observed or abstract variables.
\end{abstract}

Keywords : scientific reasoning, guided inquiry, scaffolding, heat and temperature

This is an open access article distributed under the Creative Commons 4.0 Attribution License, which permits unrestricted use, distribution, and reproduction in any medium, provided the original work is properly cited. $\odot 2020$ by author and Universitas Negeri Padang.

\section{PENDAHULUAN}

Sumber daya manusia menjadi penyebab utama perubahan dalam pendidikan dan tingkat kemampuan seseorang. Pendidik harus mampu mengembangkan pembelajaran yang tidak hanya berorientasi pada penguasaan konsep pelajaran namun juga pada konten yang lebih tinggi (Nia, Supeno dan Iwan, 2016:474). Salah satunya adalah mengembangkan kemampuan penalaran ilmiah siswa. Peningkatan kemampuan penalar an ilmiah perlu menjadi perhatian khusus dan diterapkan dalam pengajaran ilmu pengetahuan.

Dalam menjelaskan dan menyampaikan argumen ilmiah, siswa memerlukan kemampuan penalaran ilmiah. Menurut Coletta, Phillips, Savinainen, dan Steinert (2008:27), kemampuan penalaran ilmiah mempengaruhi prestasi akademik siswa. Hal yang saman juga diperoleh oleh Bhat (2014:86) yang menyebutkan bahwa kemampuan penalaran ilmiah siswa menjadi prediktor kemampuan akademik siswa. Ketika siswa mampu membuat sebuah argumentasi, ia akan mengembangkan pemahaman yang utuh akan suatu konsep. Dengan menggunakan prinsip ilmiah untuk menjelaskan sebuah fenomena, siswa mampu membangun pemahaman yang mendalam (McNeill dan Krajcik, 2008:122).
Hasil studi pendahuluan yang telah dilakukan di SMA Negeri 1 Krian Sidoarjo menunjukkan bahwa kemampuan penalaran ilmiah siswa masih rendah. Hal ini terlihat dari pola penalaran yang dimiliki siswa. Sebanyak 44 $\%$ siswa berada pada pola correlational reasoning dengan kategori NR (No Relation ship). Sebesar $25 \%$ siswa berada pada pola proportional reasoning dengan kategori $\mathrm{AD}$ (Additive) dan sebanyak 63\% siswa memiliki pola probabilistic reasoning dengan kategori AP (Approximate) (Rimadani, Parno, dan Diantoro, 2017: 833). Rendahnya kemampuan penalaran siswa disebabkan karena kurangnya pemahaman siswa terhadap suatu materi atau konsep (Pyper, 2012:65).

Suhu dan kalor merupakan salah satu materi yang sulit dan kurang dipahami oleh siswa (Setyadi dan Komalasari, 2012:46). fenomena terkait materi suhu dan kalor sangat erat kaitannya dengan kehidupan sehari-hari, namun hal tersebut sulit dijelaskan secara ilmiah oleh siswa. Hal ini disebabkan materi suhu dan kalor yang bersifat abstrak (Ornek, Robinson, dan Haugan, 2008:32). Siswa sulit membedakan antara suhu dan kalor (Alwan, 2011:603). 
Beberapa siswa mampu menunjukkan bahwa suhu dan kalor berbeda, namun siswa masih memiliki pemikiran yang salah tentang suhu dan kalor. Misalnya, besarnya suhu sebanding dengan ukuran benda, suhu dapat ditransferkan, benda memiliki kalor, dan terdapat kalor dingin dan kalor panas (Alwan, 2011:603; Chu, Treagust, Yeo, dan Zadnik, 2012:1512).

Guru perlu merancang pembelajaran yang tepat sehingga dapat mengatasi kesulitan siswa pada materi suhu dan kalor. Rancangan pembelajaran dapat dibuat dengan menghubung kan konsep fisika dengan fenomena nyata yang terjadi (Fortus, Adams, Krajcik, dan Reise, 2015:1409). Hal ini sesuai dengan karakteristik materi suhu dan kalor. Mengacu pada Kurikulum 2013, pembelajaran yang dirancang dapat berupa pembelajaran konstruktivis yang menuntut siswa untuk berperan aktif di kelas. Melalui kegiatan pembelajaran, siswa dapat mengaitkan pembelajaran di dalam kelas dengan pengalaman sehari-hari di kehidupannya (Akinwumi dan Bello, 2015:171), sehingga meningkatkan kemampuan penalaran ilmiah siswa.

Pembelajaran yang dapat membuat siswa berperan aktif adalah pembelajaran inquiry. Penggunaan pembelajaran inquiry di dalam kelas mampu meningkatkan kemampuan penalaran ilmiah siswa (Steinberg dan Cormier, 2013:8). Ada beberapa jenis pembelajaran inquiry, salah satunya adalah guided inquiry. Blanchard, Southerland, Osborne, Sampson, Annetta, dan Granger (2010:578) menyebutkan bahwa pembelajaran guided inquiry lebih efektif

\section{METODE PENELITIAN}

Penelitian dilakukan di SMA Negeri 1 Krian Sidoarjo dengan dengan melibatkan 29 siswa kelas X MIA 1. Penelitian menggunakan mixed-method dengan desain embedded experimental seperti pada Gambar 1.

Intrumen penelitian terdiri dari instrumen perlakuan dan instrumen pengukuran. Instrumen perlakuan memuat silabus, RPP, LKS, dan lembar observasi pembelajaran. RPP dikembangkan sesuai pembelajaran guided inquiry berstrategi scaffolding. Sedangkan daripada pembelajaran tradisional. Guided inquiry menempatkan siswa bekerja dalam kelompok sehingga siswa dapat berdiskusi dan bertukar pikiran selama pembelajaran. Namun, kontrol dari guru tetap diperlukan untuk mengawasi dan mengatasi kesulitan siswa selama berdiskusi. Oleh sebab itu, diperlukan suatu strategi yang dapat membantu siswa selama pembelajaran.

Salah satu strategi yang dapat digunakaan adalah scaffolding. Pemberian scaffolding kepada siswa dapat meningkatkan pemahaman dan kemampuan belajarnya (Pol, Volman, Oort, dan Beishuizen, 2015:618). Scaffolding memberikan manfaat bagi siswa yang kurang memahami materi sehingga menjadi siswa yang lebih kompeten dalam menyelesaikan permasalahan. Wu, Weng, dan She (2016:12) juga menyebutkan bahwa pemberian scaffolding dapat meningkatkan kemampuan penalaran ilmiah siswa.

Berdasarkan kajian-kajian penelitian yang telah dilakukan, pembelajaran guided inquiry dan scaffolding penting dilakukan untuk mengatasi rendahnya kemampuan penalaran ilmiah siswa. Dengan menggabungkan sisi positif dari masingmasing pembelajaran, guided inquiry perlu dikolaborasikan dengan scaffolding untuk mengoptimalkan pengembang an dan peningkatan kemampuan penalaran ilmiah. Adapun tujuan dilakukannya penelitian ini adalah untuk menganalisis kemampuan penalaran ilmiah siswa melalui pembelajaran guided inquiry berstrategi scaffolding pada materi suhu dan kalor.

instrumen pengukuran terdiri dari tes kemampuan penalaran ilmiah siswa. Tes kemampuan penalaran ilmiah terdiri dari 3 pola penalaran ilmiah oleh Lawson (2004:315) yaitu proportional reasoning $(\mathrm{P} 1)$, probabilistic reasoning $(\mathrm{P} 2)$, dan correlational reasoning $(\mathrm{P} 3)$. Tes ini digunakan untuk melihat pola penalaran ilmiah siswa. Sebaran butir pertanyaan penalaran ilmiah siswa berdasarkan pola penalaran ilmiah disajikan pada Tabel 1. 


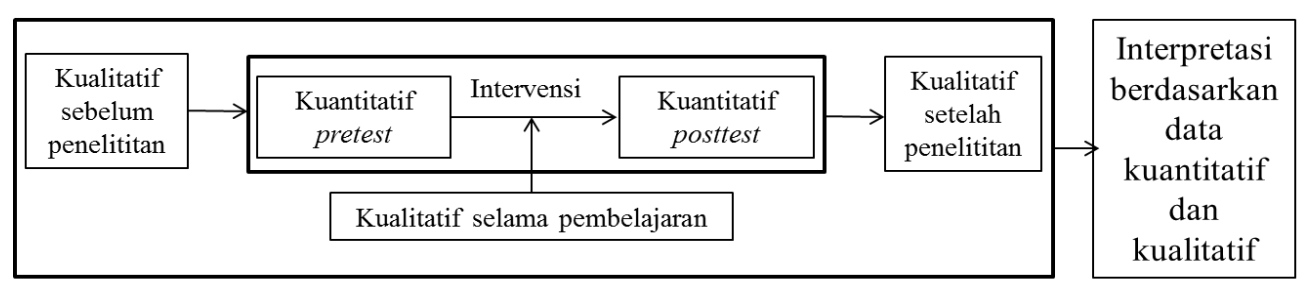

Gambar 1. Desain Penelitian (Sumber: Creswell dan Clark, 2007:68)

Tabel 1. Sebaran Butir Pertanyaan Penalaran Ilmiah Siswa berdasarkan Pola Penalaran Ilmiah

\begin{tabular}{|l|c|}
\hline \multicolumn{1}{|c|}{$\begin{array}{c}\text { Pola } \\
\text { Penalaran Ilmiah }\end{array}$} & Butir Soal \\
\hline $\begin{array}{l}\text { Proportional } \\
\text { Reasoning }\end{array}$ & 3,4 \\
\hline $\begin{array}{l}\text { Probabilistic } \\
\text { Reasoning }\end{array}$ & 5 \\
\hline $\begin{array}{l}\text { Correlational } \\
\text { Reasoning }\end{array}$ & 1,2 \\
\hline
\end{tabular}

Instrumen tes kemampuan penalaran ilmiah terdiri dari 5 soal uraian. Uji coba dilakukan untuk mengetahui validitas dan reliabilitas instrumen tes. Hasil uji coba instrumen menunjukkan bahwa instrumen tes penalaran ilmiah adalah valid dan reliabel $(\mathrm{r}=0.848)$.

Data kuantitatif kemampuan penalaran ilmiah siswa dianalisis menggunakan uji beda. Hal ini dilakukan untuk mengetahui perbedaan kemampuan penalaran ilmiah siswa sebelum dan setelah mengikuti pembelajaran. Selanjutnya, untuk mengetahui peningkatan kemampuan penalaran ilmiah siswa dianalisis menggunakan $N$-Gain, dan $d$-effect size untuk mengetahui efek pelaksanaan pembelajaran terhadap kemampuan penalaran ilmiah siswa. Data kualitatif kemampuan penalaran ilmiah dianalisis dengan melakukan reduksi data dan pengkodean menggunakan rubrik pola penalaran ilmiah.

\section{HASIL DAN PEMBAHASAN}

Hasil pretest dan posttest digunakan untuk mengukur kemampuan penalaran ilmiah siswa. Hasil analisis deskriptif kemampuan penalaran ilmiah siswa disajikan pada Tabel 2.

Tabel 2. Deskripsi Kemampuan Penalaran Ilmiah Siswa

\begin{tabular}{|c|c|c|}
\hline $\begin{array}{c}\text { Unsur-unsur } \\
\text { Statistik }\end{array}$ & Pretest & Posttest \\
\hline$N$ & 29 & 29 \\
$\bar{X}$ & 45,64 & 66,17 \\
$X_{\min }$ & 23,81 & 63,67 \\
$X_{\max }$ & 42,86 & 85,71 \\
$S D$ & 10,83 & 11,54 \\
\hline
\end{tabular}

Tabel 2 menunjukkan bahwa terdapat perbedaan kemampuan penalaran ilmiah siswa sesudah pembelajaran guided inquiry berstrategi scaffolding pada materi suhu dan kalor. Sebelum perlakuan, kemampuan penalaran siswa diuji terlebih dahulu. Dari hasil pretest diperoleh nilai rata-rata sebesar 45,64. Hal ini menunjukkan bahwa kemampuan penalaran siswa rendah. Rimadani, dkk. (2017: 838), Erlina, Susantini, dan Wasis (2018:1) dalam penelitiannya menemukan bahwa penalaran ilmiah siswa pada materi suhu dan kalor masih tergolong rendah. Selanjutnya diterapkan pembelajaran guided inquiry berstrategi scaffolding. Lalu setelah perlakuan, kemampuan penalaran ilmiah siswa diuji kembali. Nilai rata-rata kemampuan penalaran ilmiah siswa meningkat pada saat posttest.

Nilai pretest dan posttest diuji normalitas dahulu. Kemudian selanjutnya diuji beda. Hasil uji normalitas nilai pretest dan posttest kemampuan penalaran ilmiah siswa disajikan pada Tabel 3.

Tabel 3. Hasil Uji Normalitas

\begin{tabular}{|c|c|c|}
\hline \multirow{2}{*}{ Pretest } & $\begin{array}{c}\text { Kolmogorov- } \\
\text { Smirnov } \\
\text { Sig }\end{array}$ & \multirow{2}{*}{ Kesimpulan } \\
\hline Posttest & 0,113 & Normal \\
\hline
\end{tabular}

Hasil uji normalitas menunjukkan bahwa nilai pretest kemampuan penalaran ilmiah siswa terdistribusi normal. Namun, nilai posttest tidak terdistribusi normal. Selanjutnya, karena ada data yang tidak terdistribusi normal maka uji lanjut yang dilakukan adalah uji beda menggunaan wilcoxon. Uji beda menggunakan wilcoxon dilakukan untuk mengetahui perbedaan nilai pretest dan posttest.

Hasil uji beda wilcoxon diperoleh nilai sig(p-value) sebesar 0,000. Hal ini berarti terdapat perbedaan signifikan pada nilai pretest dan posttest kemampuan penalaran ilmiah siswa. 
Peningkatan nilai rata-rata pretest dan posttest dapat dilihat dari hasil perhitungan $\mathrm{N}$-Gain yaitu sebesar 0,37 (kategori sedang). Besar efek pembelajaran guided inquiry berstrategi scaffolding dihitung menggunakan d-effect size. Dari hasil perhitungan diperoleh 1,69 (efek kuat).

Selama pelaksanaan pembelajaran guided inquiry berstrategi scaffolding, siswa berperan aktif. Secara implisit siswa melakukan tahaptahap pembelajaran yang mengarah pada penalaran ilmiah. Hal ini membuktikan bahwa pembelajaran guided inquiry dapat melatihkan penalaran ilmiah siswa (Wilson, Taylor, Kowalski, dan Carlson, 2009:276; Salim, Kadir, dan Kodirum, 2018:311), begitu juga dengan pemberian scaffolding yang ikut membantu meningkatkan penalaran ilmiah siswa (Wu, dkk., 2016:12).

Siswa memperoleh konsep dan fakta ilmiah melalui diskusi dengan teman kelompoknya. Walaupun semua konsep yang diperoleh siswa tidak berasal dari siswa itu sendiri melainkan juga ada dari bantuan guru berupa pemberian scaffolding selama pembelajaran. Kegiatan diskusi akan terasa lebih bermakna ketika seorang siswa yang awalnya tidak tahu menjadi tahu (Smith, Wood, Adams, Wieman, Knight, Guild, dan Su, 2009:122). Penjelasan guru akan memperkuat konsep yang didapat sehingga pemahaman siswa terhadap suatu konsep tersebut meningkat (Smith, Wood, Krauter, dan Knight, 2011:55)

Kemampuan penalaran ilmiah siswa dibedakan menjadi 3 pola penalaran ilmiah. Adapun pola penalaran ilmiah tersebut adalah yang pertama proportional reasoning, lalu probabilistic reasoning, dan yang terakhir correlational reasoning. Pertama, pola proportional reasoning berkaitan dengan bagaimana cara menafsirkan hubungan antar variabel yang diamati. Kedua, pola probabilistic reasoning berkaitan dengan kemampuan menggunakan informasi dalam menentukan kebenaran suatu kesimpulan. Ketiga, pola correlational reasoning berkaitan dengan kemampuan menentukan hubungan fenomena yang diteliti. Setiap pola penalaran ilmiah siswa terdiri dari level yang berbeda-beda. Sebaran level penalaran ilmiah berdasarkan pola pelanaran ilmiah disajikan pada Tabel 4.

Pola penalaran ilmiah pertama yaitu Proportional Reasoning terdiri dari 2 soal uraian yaitu soal nomor 3 dan 4. Salah satu soal yang diberikan pada pola ini berkaitan dengan konsep konduksi. Diberikan sebuah gambar dua logam berbeda yang disatukan. Selanjutnya siswa diminta untuk menentukan suhu di antara sambungan kedua logam tersebut. Jawaban siswa sebelum dan sesudah pembelajaran dapat dilihat pada Gambar 2. Pola penalaran ilmiah siswa sebelum dan sesudah intervensi disajikan pada Gambar 3.

(a)

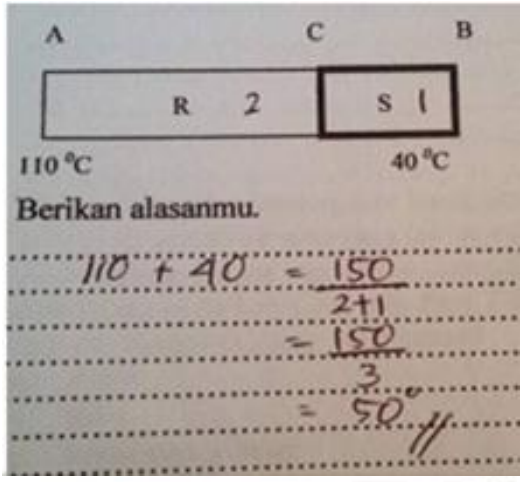

(b)

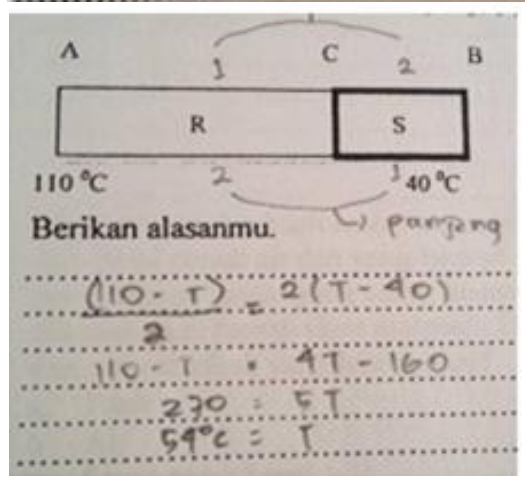

Gambar 2. Pola Proportional Reasoning Siswa

(a) Sebelum Intervensi dan

(b) Sesudah Intervensi

Tabel 4. Kategori Level Pola Penalaran Ilmiah Siwa

\begin{tabular}{|c|c|c|c|c|c|}
\hline \multirow{2}{*}{$\begin{array}{c}\text { Pola } \\
\text { Penalaran } \\
\text { Ilmiah }\end{array}$} & 1 & 2 & 3 & 4 & 5 \\
\cline { 2 - 6 } & Intuitive & Aditive & Transitional & Ratio & - \\
\hline P2 & Intuitive & Aproximate & Quantitative & - & - \\
\hline P3 & Intuitive & No relationship & One cell & Two cell & Correlation \\
\hline
\end{tabular}

Sumber: Lawson, 2004:315 
Pada level 1 (Intuitive) terdapat selisih $17,22 \%$ antara pretest-posttest. Level 2 (Aditive) menunjukkan peningkatan sebesar 5,9\%. Level 3 (Transsitional) terjadi peningkatan sebesar 13,79\%. Pada level 4 (Ratio) terjadi peningkatan sebesar 6,9\%. Secara umum, jawaban siswa mengalami peningkatan level pola penalaran ilmiah. Pada saat pretest, kebanyakan siswa berapa pada level 1 dan 2 . Sedangkan pada saat posttest beralih menjawab ke level 3 dan 4 , serta masih ada siswa yang tidak menjawab (TM). Meskipun pola penalaran ilmiah siswa pada level 2 masih menjadi pola penalaran tertinggi yang diperoleh siswa dalam menjawab soal.

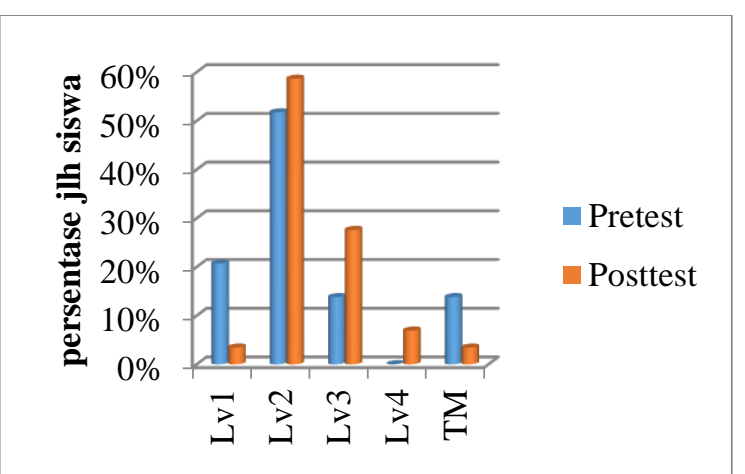

Gambar 3. Peningkatan Pola Proportional Reasoning

Fisika menggunakan matematika sebagai alat dalam memecahkan permasalahan (Redish, 2005:1). Pada butir soal ini kemampuan matematis sangat diperlukan. Gambar 2 merupakan contoh perubahan jawaban siswa saat sebelum dan sesudah melakukan pembelajaran guided inquiry berstrategi scaffolding. Jawaban siswa saat pretest belum benar karena siswa belum mengerti bagaimana mengelola suatu perbandingan dengan rumus yang digunakan untuk menyelesaikan suatu permasalahan.

Level penalaran ilmiah siswa berada pada level 2 (Aditive), yang artinya siswa menggunakan strategi penyelesaian tetapi fokus pada hal lain. Pada Gambar 3 siswa belum bisa menjawab soal konduksi dengan benar karena siswa belum memahami persamaan matematis apa yang akan digunakan. Pada saat posttest siswa mengalami peningkatan level penalaran ilmiah ke level 3 (Transitional) dan level 4 (Ratio), yang berarti bahwa siswa telah mampu menggunakan persamaan dengan rasio sehingga dapat menentukan nilai dengan tepat. Terbukti ketika posttest siswa menjawab dengan benar dan tepat. Siswa menunjukkan bahwa mereka mampu menerapkan dan menggunakan persamaan matematis dengan benar.

Hasil pola proportional reasoning menunjukkan bahwa hanya dua siswa yang sampai pada level 4 (Ratio). Hal tersebut sesuai dengan beberapa penelitian bahwa beberapa siswa SMA fokus hanya pada kuantitas pada saat menalar tentang masalah proportional, sementara siswa yang lain menghubungkan kuantitas tetapi tidak memperhatikan hubungan multiplikatif antara variabel-variabelnya (Riyadi, Qamar, Wulandari, dan Oktaviana, 2019:1). Hal tersebut membuat perbandingan yang absolut daripada perbandingan relatif.

Pola penalaran ilmiah kedua yaitu Probabilistic Reasoning terdiri dari satu soal uraian. Soal berkaitan dengan konsep pengaruh kalor. Diberikan gambar sebuah grafik perubahan suhu terhadap waktu. Siswa diminta untuk menyimpulkan data yang ada pada grafik. Perubahan jawaban siswa sebelum dan sesudah pembelajaran terlihat pada Gambar 4.

(a)

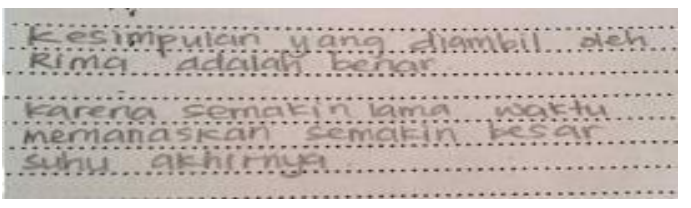

(b)

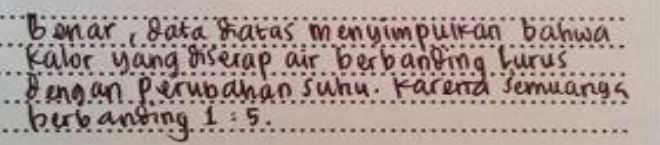

Gambar 4. Pola Probabilistic Reasoning Siswa

(a) Sebelum Intervensi dan

(b) Sesudah Intervensi

Dari jawaban yang diberikan terjadi peningkatan level pola penalaran siswa. Pada saat pretest, siswa masih banyak berada pada level 1(Intuitive) dan 2 (Aproximate). Sedangkan pada saat posttest, pola penalaran siswa sudah beralih ke level 2 (Aproximate) dan 3 (Quantitative). Peningkatan yang cukup tinggi terjadi pada level 2. Terjadi peningkatan sebesar $48,28 \%$ (14 siswa) di level 2, yang pada saat pretest hanya $48,28 \%$ (14 siswa) menjadi 96,55\% (28 siswa). Kemudian di level tertinggi yakni level 3, hanya satu orang yang menjawab soal dengan level tersebut disaat posttest. Jika saat pretest masih ada siswa yang tidak menjawab soal, ketika posttest sudah tidak ada siswa yang tidak menjawab. Gambar 5 yang menunjukkan peningkatan pola penalaran ilmiah. 


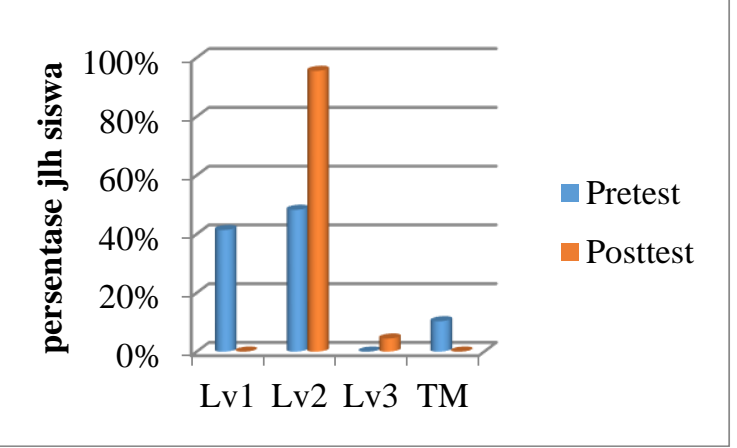

Gambar 5. Peningkatan Pola Probabilistic Reasoning

Probabilistic reasoning merupakan kemampuan menggunakan informasi dalam menentukan kebenaran suatu kesimpulan (Lawson, 2004:315). Pada kasus ini suatu informasi diberikan berupa diagram garis yang menunjukkan perubahan suhu benda yang berbanding lurus dengan waktu.

Gambar 4a dan 4b. menunjukkan pola jawaban siswa pada saat pretest dan posttest, yang berada pada level 2 (Approximate). Siswa mengaitkan pola probabilistic reasoning untuk membuat keputusan berdasarkan kemungkinankemungkinan yang tersedia dalam data untuk menjawab pertanyaan (Makar dan Rubin, 2009:83). Namun, siswa menghubungkan kemungkinan-kemungkinan tanpa mengaitkan data kuantitatif yang ada dalam grafik. Hal ini menunjukkan bahwa siswa hanya memberikan penjelasan dan alasan dengan deskripsi kualitatif saja. Padahal yang diharapkan pada butir soal ini adalah deskripsi kualitatif dan kuantitatif sebagai bukti dari pemahaman siswa atas informasi yang diberikan.

Siswa belum mampu mengelola informasi dengan baik dan lengkap dari suatu data. Namun, hasil jawaban siswa dalam menjawab soal pola probabilistic reasoning menunjukkan bahwa siswa mampu membaca data, yang artinya siswa sudah bisa untuk menginterpretasi, mengintegrasi, dan mencari hubungan dari informasi yang berada dalam tabel atau grafik (Sari, Budayasa, dan Juniati, 2017:1).

Pola penalaran ilmiah ketiga yaitu Correlational Reasoning terdiri dari dua soal uraian. Salah satu soal berkaitan dengan konsep perpindahan kalor. Disajikan narasi mengenai nelayan yang pergi melaut pada malam hari. Lalu siswa diminta menjelaskan hubungan peristiwa yang terjadi dengan perpindahan kalor. Perubahan jawaban siswa sebelum dan sesudah pembelajaran dapat dilihat pada Gambar 6 .

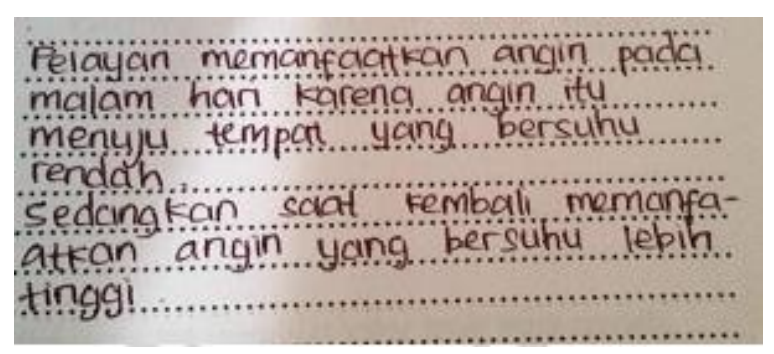

(a)

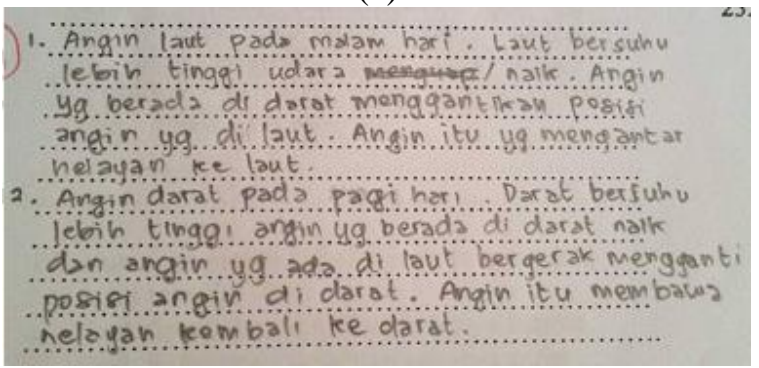

(b)

Gambar 6. Pola Correlational Reasoning Siswa

(a) Sebelum Intervensi dan (b) Sesudah Intervensi

Peningkatan pola penalaran ilmiah siswa sebelum dan sesudah pembelajaran guided inquiry berstrategi scaffolding yang ditunjukkan pada Gambar 7 menunjukkan bahwa $41,37 \%$ (12 siswa) siswa pada saat pretest berada pada level 2 (No Relationship). Sebesar $3,44 \%$ (1 siswa) tergolong pada level 1. Kemudian pada saat posttest, pola correlational reasoning siswa sudah berubah ke level 4 (Two Cell) sebesar 41,37\% (12 siswa), dan tidak ada siswa yang tergolong level 1 (Intuitive).

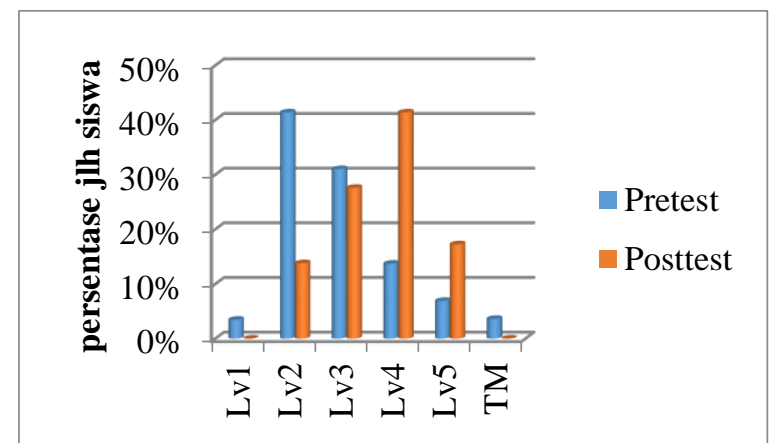

Gambar 7. Peningkatan Pola Correlational Reasoning

Correlational reasoning merupakan kemampuan siswa untuk menentukan hubungan dalam fenomena yang diteliti (Lawson, 2004:315). Peningkatan pada pola correlational reasoning level 5 (Correlational) hanya sebesar $10,35 \%$. Hal ini menunjukkan bahwa tidak semua siswa mampu menalar sejauh level 5 atau mengkorelasikan semua variabel menjadi suatu penjelasan ilmiah yang baik dan benar. Hal ini 
sesuai dengan penelitian sebelumnya yang menyatakan bahwa siswa sekolah menengah pertama hingga perguruan tinggi masih sulit menghubungkan atau variabel-variabel tertentu dalam observasi (Riyadi, dkk., 2019:4).

Russ, Hammer, dan Mikeska (2008:523) mengidentifikasi bahwa penalaran sebab-akibat merupakan bagian dari membangun penjelasan untuk pemahaman ilmiah. Jika siswa diberikan kesempatan untuk berpikir secara logika, merefleksikan pengalaman, dan memberikan alasan pada penalarannya, maka pembelajaran yang lebih efektif akan terlaksana (Akinwumi dan Bello, 2015:171). Begitu juga dengan semua pola penalaran ilmiah yang dibahas, bahwa selalu ada penalaran sebab-akibat dalam fenomena yang harus dianalisis oleh siswa. Siswa mampu menalar lebih dalam fenomena untuk dikaitkan dalam konsep fisis. Kemampuan penalaran merupakan aspek yang sangat penting bagi manusia. Kemampuan untuk berpikir dan bernalar secara logis dibutuhkan untuk memecahkan masalah yang diperlukan (Bhat, 2014:86).

Secara umum, kemampuan penalaran ilmiah siswa meningkat pada seluruh pola penalaran ilmiah setelah mengikuti pembelajaran guided inquiry berstrategi scaffolding. Terbukti bahwa pembelajaran ini cukup efektif dalam meningkatkan kemampuan penalaran ilmiah siswa.

\section{KESIMPULAN}

Berdasarkan hasil analisis data yang dilakukan dalam penelitian ini, maka dapat disimpulkan bahwa penerapan pembelajaran guided inquiry berstrategi scaffolding dapat meningkatkan kemampuan penalaran ilmiah siswa kelas X MIA 1 SMA Negeri 1 Krian Sidoarjo pada materi suhu dan kalor. Guru diharapkan dapat menerapkan pembelajaran guided inquiry berstrategi scaffolding sebagai alternatif solusi untuk mengembangkan kemampuan penalaran ilmiah siswa.

\section{DAFTAR PUSTAKA}

Akinwumi, M.O., and Bello, T.O. 2015. Relative Effectiveness of Learning Cycle Model and Inquiry-Teaching Approaches in Improving Students'Learning Outcomes in Physics. Journal of Education and Human Development, 4(3): 169-180.
Alwan, A. A. 2011. Misconception of Heat and Temperature Among Physics Students. Procedia Social and Behavioral Sciences, 12: 600-614.

Bhat, M. A. 2014. Construction and Evaluation of Reasoning Ability Test. Journal of Educational Studies, 1(2), 47-52.

Blanchard, M. R., Southerland, S. A., Osborne, J. W., Sampson, V. D., Annetta, L. A., \& Granger, E. M. 2010. Is Inquirypossible in Light of Accountability?: A Quantitative Comparison of The Relative Effectiveness of Guided Inquiry and Verification Laboratory Instruction. Science Education, 94(4), 577-616.

Chu, H. E., Treagust, D. F., Yeo, S., And Zadnik, M. 2012. Evaluation of Studentse Understanding of Thermal Concepts in Everyday Contexts. International Journal of Science Education, 34(10): 1509-1534.

Coletta, V.P., Phillips, J. A., Savinainen, A. \& Steinert, J.J. 2008. Comment on "The Effects Of Students' Reasoning Abilities on Conceptual Understanding and Problem-Solving Skills in Introductory Mechanics". European Journal of Physics, 29(5): 25-27.

Cresswell, J. W. dan Clark, P. 2007. Designing and Conducting Mixed Methods Research. California: Sage Publication, Inc.

Fortus, D., Adams, L. M. S., Krajcik, J., and Reise, B. 2015. Assessing the Role of Curriculum Coherence in Student Learning About Energy. Journal of Research in Science Teaching, 52(10), 1408-1425.

Lawson, A.E. 2004. The nature and development of scientific reasoning: A synthetic view. International Journal of Science and Mathematics Education, 2(3), 307-338.

Makar, K., \& Rubin, A. 2009. A framework for thinking about informal statistical inference. Statistical Education Research Journal, 8(1), 82-105.

Mcneill, K. L. \& Krajcik, J. 2008. Inquiry and Scientific Explanations: Helping Students Use Evidence and Reasoning, 121-134.

Erlina, E., E Susantini., Wasis. 2018. Common False of Student's Scientific Reasoning in Physics Problems. Journal of Physics: Conf. Series 1108, 1-6.

Nia, E., Supeno., dan Iwan, W. 2016. Penalaran Ilmiah dalam Pembelajaran Fisika. Prosiding Seminar Nasional Tahun 2016 "Mengubah Karya Akademik Menjadi 
Karya Bernilai Ekonomi Tinggi”. Surabaya: 23 Januari 2016. Hal. 473-480.

Ornek, Funda, William R. Robinson, and Mark P. Haugan. 2008. What Makes Physics Difficult. International Journal of Environmental \& Science Education, 2008, 3(1), 30-34.

Pyper, B. A. 2012. Changing Scientific Reasoning and Conceptual Understanding in College Students. AIP Conference Proceedings, 1413: 63-65.

Redish, E,F. 2005. Problem Solving and The Use of Math In Physics Courses. Presented at the conference, World View on Physics Education in 2005: Focusing on Change, Delhi, August 21-26, 2005, 1-10.

Rimadani, E., Parno., dan Diantor, M. 2017. Identifikasi Kemampuan Penalaran Ilmiah Siswa SMA pada Materi Suhu dan Kalor. Jurnal Pendidikan: Teori, Penelitian, dan Pengembangan, 2(6):833-839.

Riyadi, S., Qamar, K., Wulandari, T,C., and Oktaviana, I. 2019. Mathematical connection: how is student's ability to complete a two-variable linear equation system?. Journal of Physics: Conference Series, 1321 (2019) 032001, 1-6.

Russ, R. S., Scherr, R. E., Hammer, D. \& Mikeska, J. 2008. Recognizing mechanistic reasoning in student scientific inquiry: A framework for discourse analysis developed from philosophy of science. Science Education, 92(3), 499525.

Salim, Kadir, dan Kodirun. 2018. Applying Guided Inquiry Learning Method with Contextual Approach to Improve Students' Ability of Mathematical Reasoning. Advances in Social Science, Education and Humanities Research (ASSEHR), 227, 311316.

Sari, D,I., Budayasa, I,K., dan Juniati, D. 2017. Probabilistic Thinking of Elementary School Students in Solving Probability Tasks Based on Math Ability. International Conference on Mathematics:
Pure, Applied and Computation AIP Conf. Proc. 1867, 020028-1-020028-10.

Setyadi, E. K., dan Komalasari, A. 2012. Miskonsepsi tentang Suhu dan Kalor pada Siswa Kelas 1 di SMA Muhammadiyah Purworejo, Jawa Tengah. Berkala Fisika Indonesia, 4(1\&2): 46-49.

Smith, M. K., Wood, W. B., Adams, W. K., Wieman, C., Knight, J. K., Guild, N., \& $\mathrm{Su}$, T. T. 2009. Why peer discussion improves student performance on in-class concept questions. Science, 323(5910), 122-124.

Smith, M. K., Wood, W. B., Krauter, K., \& Knight, J. K. 2011. Combining peer discussion with instructor explanation increases student learning from in-class concept questions. Life Sciences Education, 10(1), 55-63.

Steinberg, R., \& Cormier, S. 2013. Understanding and Affecting Science Teacher Candidates' Scientific Reasoning in Introductory Astrophysics, 020111, 110.

van de Pol, J., Volman, M., Oort, F., and Beizhuizen, J. 2015. The effects of scaffolding in the classroom: support contingency and student independent working time in relation to student achievement, task effort and appreciation of support. Instructional Science, 43, 615641.

Wilson, C. D., Taylor, J. A., Kowalski, S. M., \& Carlson, J. 2009. The relative effects and equity of inquiry-based and commonplace science teaching on students' knowledge, reasoning, and argumentation. Journal of Research in Science Teaching, 47(3), 276301.

Wu, H. L., Weng, H. L., \& She, H. C. 2016. Effects of scaffolds and scientific reasoning ability on web-based scientific inquiry. International Journal of Contemporary Educational Research, 3(1), 12-24. 